\title{
Seeking the Mantle of "Opportunity": Presidential Politics and the Educational Metaphor, 1964-2000
}

\author{
FREDERICK M. HESS and PATRICK J. MCGUINN
}

\begin{abstract}
Traditionally, scholars have accorded the issue of education only a minor role in understanding presidential elections. The authors suggest that this is a mistake and offer a reassessment of education's symbolic and substantive role in contemporary presidential politics. In particular, education's embodiment of opportunity and personal responsibility made it a crucial metaphor in post-Great Society politics. The new conservatism that emerged in 1964 would enjoy success with its sunny promise of individual opportunity but would eventually be torn between its implicit guarantee of universal opportunity and opposition to activist government. In the early 1990s, centrist Democrats used education to exploit this tension and slip the party's "tax and spend" reputation. Republican nominees, in turn, struggled to demonstrate their commitment to extending opportunity to all Americans. In 2000, Republican candidate George $W$. Bush used an accountability-driven education program to neutralize the Democratic advantage but, in so doing, created a potential party rift with implications for future presidential politics and national education policy.
\end{abstract}

TRADITIONALLY, SCHOLARS have accorded the issue of education only a minor role in understanding presidential elections. This accounting fails to appreciate the pivotal symbolic role that education has played in national politics as both major parties have sought to accommodate broad social and political changes. Here, we reassess education's symbolic and substantive role in contemporary presidential politics. Such an examination helps illuminate the contours of national educational policy, especially in the case of issues such as school choice and accountability. Education has been far more

EDUCATIONAL POLICY, Vol. 16 No. 1, January and March 2002 72-95

(C) 2002 Corwin Press 
intertwined with national politics during the past three decades than is generally recognized. In the postindustrial economy and the post-New Deal political era, a growing belief in the importance of educational opportunity infused education with unprecedented political significance. The parties would discover that education provided a way to tap the American commitment to both opportunity and individual responsibility.

That education has come to play an important symbolic and substantive role in national politics should not be surprising. Political thinkers from Plato to Rousseau to Jefferson to Dewey have seized upon the revolutionary capacity of schooling to reshape societal arrangements without requiring states to coerce adult citizens. From Plato's "republic" to Dewey's "lab school," philosophers have understood that society could use schooling to forge ideal citizens. In the contemporary American context, there resides the hope that schools can shape skilled, responsible, and self-sufficient citizens, strengthening the nation and alleviating any further need for government assistance.

In exploring the relationship between education and presidential politics, it is important not to overstate the point. The federal government has always played a small programmatic role in schooling (Kursh, 1965; Wirt \& Kirst, 2001). Before the 1960s, the federal role in K-12 education was minimal, and even after the 1965 passage of Elementary and Secondary Education Act (ESEA), the federal government has generally contributed less than $10 \%$ of total education spending (National Center for Education Statistics, 2000). ${ }^{1}$ It was not until the 1990s that education emerged as an issue in national elections (see Table 1). The larger political significance of education, however, has far exceeded the direct federal role (Thompson, 1990).

Central to the strategic vision of both major parties in recent decades was the desire of Republicans and Democrats to position themselves as defenders of an "opportunity society." Scholars have long noted that American political culture is marked by faith in both individual responsibility and the promise of equal opportunity (Feldman, 1988). In the 1960s, established Republican doctrine embraced individualism and localism and flatly rejected any government role in proactively seeking to extend opportunity. In 1964, however, a new strain of Republicanism emerged. It offered a sunnier conservatism, one suffused with the implicit assurance that opportunity was the birthright of every American. Although this new conservatism would prove politically potent, it would eventually be caught between its promise to democratize opportunity in a society marked by inequality and its philosophical hostility toward activist federal government. Historically, the Democrats, with a base of minority, urban, and disadvantaged voters, were inclined to promote a more activist social agenda. However, growing middle-class dis- 
Table 1

Public Perceptions of the Nation's Most Important Problem, 1960-2000

\begin{tabular}{|c|c|c|c|c|}
\hline Year & Candidates & $\begin{array}{l}\text { Issue Rated Most } \\
\text { Important by Voters }\end{array}$ & $\begin{array}{c}\text { Relative Ranking } \\
\text { of Education }\end{array}$ & $\begin{array}{c}\text { Standardized } \\
\text { Rank of } \\
\text { Education }\end{array}$ \\
\hline 1960 & Kennedy-Nixon & Foreign relations & $14^{\text {th }}$ of 20 issues & Lower $33 \%$ \\
\hline 1964 & Johnson-Goldwater & Civil rights & 24 th of 24 issues & Last \\
\hline 1968 & Humphrey-Nixon & Vietnam & 17 th of 17 issues & Last \\
\hline 1972 & McGovern-Nixon & Vietnam & 26 th of 26 issues & Last \\
\hline 1976 & Carter-Ford & Inflation & $\begin{array}{l}\text { Not listed among } \\
27 \text { issues }\end{array}$ & Last \\
\hline 1980 & Carter-Reagan & Inflation & $23 \mathrm{rd}$ of 41 issues & Middle $33 \%$ \\
\hline 1984 & Mondale-Reagan & Recession & 17 th of 51 issues & Upper $33 \%$ \\
\hline 1988 & Dukakis-Bush & Drugs & 8 th of 26 issues & Upper $33 \%$ \\
\hline 1992 & Clinton-Bush & Economy & 5 th of 24 issues & Upper $33 \%$ \\
\hline 1996 & Clinton-Dole & Crime & 6 th of 52 issues & Upper $33 \%$ \\
\hline $2000^{\mathrm{a}}$ & Gore-Bush & Education & 1 st of 11 issues & First \\
\hline
\end{tabular}

Source. Assorted polls from the Roper Center for Public Opinion Research at the University of Connecticut (n.d.).

Note. Respondents were asked, "What do you think is the most important problem facing this country today?" All surveys were conducted within 2 months of the presidential election except for 1988 (July) and 2000 (June).

a. In 2000, the question wording was slightly different than above. It read, "What do you think is the most important problem for the government - that is the President and Congress - to address in the coming year?"

enchantment with redistributive social programs made it necessary to find another way to promote government activism. Education provided Democrats, as it would the Republicans, with an alluring synthesis of equity and opportunity. On one hand, education escaped the moral hazard dilemmas associated with the troubled politics of welfare-because no critics would argue that school spending would undermine the work ethic or self-reliance of children. On the other hand, education offered Democrats a way to steer large amounts of resources toward disadvantaged communities while focusing attention on the most sympathetic members of those communities.

These developments help illuminate how presidential politics shapes and is shaped by public policy. Classically, Downs (1957) explained why the minority party in a two-party system must alter its positions in pursuit of electoral gain and how such efforts necessitate a majority party response. The result is an unending process of issue entrepreneurship, as candidates and advocates constantly seek to discover effective issues or ways to repackage old issues (Mintrom, 2000). In this process, specific policy appeals are often of limited use in courting voters who tend to rely instead on the broader proxies of ideology and past performance. However, at times, entrepreneurs will 
stumble across issues of great symbolic impact (Carmines \& Stimson, 1989). Issues are likely to prove especially potent when they call into question the sincerity or coherence of ideological claims, because this permits the opposition to exploit the public's existing knowledge and beliefs in arguing its case. Conflicts between broad principles and programmatic proposals will inevitably exist at a given point in time, because party leaders are neither able nor willing to retool their full panoply of positions to ensure ideological consistency. In seeking to alter established positions to exploit the opposition's disparities or to address one's own vulnerabilities, reformers confront opposition from interests and party members with strong commitments to the status quo. Invested in particular positions and the party's role as defender of those stances, such constituents are unlikely to modify their position or abandon the party (Hirschman, 1970). ${ }^{3}$ Party leaders must struggle with these ideological and constituent constraints as they duel for the allegiance of the median voter. In extraordinary times, the social and political milieu may permit aspiring reformers to forge wholly new positions. At these realigning moments, the party leaders may even be able to construct new electoral coalitions (Burnham, 1970).

More commonly, existing ideological and constituency commitments make it difficult for entrepreneurs to fabricate new positions, forcing them instead to operate in a more piecemeal fashion as they seek to exploit inconsistencies and to redress exposed vulnerabilities. This intricate dance helps to shape the larger political climate-pushing issues up and down the agenda — even as the participants adjust to the currents they call forth (Kingdon, 1995). The national politics of education provide an opportunity to see how an issue was raised from the periphery to the center of political discourse, why it rose as it did, and the effect its rise had on the broader political debate. How the candidates and their parties wrestled with these tensions and the larger implications of their activity for national politics and education policy will constitute the rest of this discussion. Before pressing forward, however, it is useful to say a word about the significance of "sociotropic" voting on public policy. Political scientists have long recognized that voters are significantly influenced by what they think is best for the community or the nation - and not just by what they believe will improve their immediate personal well-being (Markus, 1988). Such attitudes are especially prevalent when voters are thinking about policies that resonate with their conceptions of a just society or affect vulnerable and sympathetic populations, as in the case of education. Party positions appeal not only to simple self-interest but also to cultural conceptions of American values and ideals. Consequently, it is important to view the political discourse not only through the narrow lens 
of particular interests but also with an eye to the values that characterize the larger culture.

Of course, any effort to provide a brief, stylized political discussion of the kind we undertake here will leave out an enormous amount of relevant discussion and useful nuance. Education is only one thread in a complex tapestry, and to try to weave the tale of decades of politics with that lone thread inevitably creates distortions and requires questionable leaps. In addition, scholars have long recognized that the modern presidency enjoys an uneasy relationship with the political parties, presenting challenges for efforts to explain evolving party conflicts by focusing on presidential activity (Milkis 1995). However, we believe these challenges are offset by the ability of this exercise to shed light on the larger educational discourse, illuminate the role of education in American politics, and clarify the impact of politics on educational policy.

\section{A GRADUALLY EMERGING FEDERAL ROLE: PRE-1964}

Prior to the 1950s, federal involvement in education was almost nonexistent. The Constitution is silent on education, and the issue was historically deemed the province of state and local government. It was not until 1867 that a tiny four-person U.S. Office of Education was established, and it was another five decades before the federal government first provided an annual appropriation for K-12 schooling.

Prior to World War II, national candidates generally ignored education. ${ }^{4}$ Education played a minor role in the political affairs of a nation where, in 1930, less than a fifth of adults older than 25 had completed high school and where progressives had fought doggedly to convince the public that schooling decisions ought to be entrusted to educational professionals (Tyack, 1974). When education did emerge as an issue, it was typically due to religious and ethnic tensions rather than more abstract concerns about school quality. ${ }^{5}$ Education gained new prominence after World War II, as high school completion became the norm and as the G.I. Bill spurred a dramatic spike in college enrollment. Whereas in 1940 just $38.1 \%$ of 25 - to 29 -year-olds had graduated high school and just 5.9\% had completed 4 years of college, by 1970 $75.4 \%$ had finished high school and $16.4 \%$ had completed 4 years of college (U.S. Department of Commerce, 1999, Table 8). For the first time, education became part of the lexicon of the working-class American and a key to economic and social mobility (Ravitch, 1983, pp. 10-16).

Education gained additional salience in the aftermath of the Supreme Court's 1954 Brown ruling on school segregation and the Soviet Union's launch of Sputnik - the first orbiting satellite-in 1957. The Supreme Court's 
Table 2

Presidential Attention to Education

\begin{tabular}{llcc}
\hline Years & \multicolumn{1}{c}{ President } & $\begin{array}{c}\text { Total Mentions of Education } \\
\text { in Presidential Public Papers }\end{array}$ & $\begin{array}{c}\text { Average Mentions } \\
\text { per Year }\end{array}$ \\
\hline $1789-1913$ & Washington-Taft & 226 & 2 \\
$1929-1933$ & Hoover & 148 & 37 \\
$1933-1945$ & Roosevelt & 382 & 29 \\
$1945-1953$ & Truman & 667 & 74 \\
$1953-1961$ & Eisenhower & 771 & 96 \\
$1961-1963$ & Kennedy & 777 & 259 \\
$1963-1969$ & Johnson & 3,104 & 621 \\
$1969-1974$ & Nixon & 1,428 & 238 \\
$1974-1977$ & Ford & 830 & 277 \\
$1977-1981$ & Carter & 2,055 & 514 \\
$1981-1989$ & Reagan & 2,497 & 312 \\
$1989-1992$ & Bush & 2,657 & 664 \\
\hline
\end{tabular}

Note. Table tallies the total mentions of the word education in the public papers of U.S. presidents through 1992.

powerful statement in Brown on the importance of equal educational opportunity, as well as the civil rights struggles of the following decade, gave rise to a public conception of education as the birthright of a free citizenry. Educational opportunity was increasingly considered vital to ensuring all Americans the chance to better their circumstances.

Sputnik recast education as an issue of national security. Republican president Dwight Eisenhower responded to the Sputnik-induced fear that the United States had fallen behind its cold war rival by championing the 1958 National Defense Education Act, which significantly increased federal support for education. Given Republican hostility to federal activism, the bill limited the role played by the federal government. Eisenhower also felt compelled to carefully pitch the initiative as a temporary response to a national emergency. Given the demands of the cold war, a commitment to education meshed neatly with the perceived demands of national security. After Sputnik and Brown, a conviction took root that education was not just a local or familial concern but a matter of social justice and national need.

Through the end of the 1950s, education remained a minor issue for presidents and for voters in national elections (see Table 1). Eisenhower, for example, referenced education in his public speeches and papers less than 100 times during his 8 years in office (see Table 2). In the 1960s, although federal education activity attracted more attention, it remained a minor component of a broad Democratic commitment to the disadvantaged. Republicans opposed federal education activity as one more manifestation of intrusive government. 
Both stances meshed with the parties' larger agendas and appealed to their traditional constituencies.

Although foreign policy and economic concerns would continue to dominate national elections and although education remained peripheral to the government's activity in areas such as social insurance and welfare, the late 1950s marked a watershed. Subsequently, presidents and presidential aspirants could no longer simply ignore education and would begin to devote increasing attention to the issue (see Table 2).

\section{FROM THE GREAT SOCIETY TO THE CONSERVATIVE MOMENT: 1964-1980}

The first pivotal change that would alter the quiet profile of education had nothing to do with education per se but had its roots in an ideological transformation that reshaped the post-1964 Republican Party. For decades, the Republican Party had been dominated by a Midwestern, fiscally prudent, localist, incrementalist, isolationist conservatism that rejected any federal responsibility for promoting an active economic or social agenda. This conservatism translated easily into education, where concerns about quality or equality were readily labeled the province of state and local governments.

In 1964, a radically different conservatism would come to the fore, championed by Republican presidential nominee (and Arizona senator) Barry Goldwater. This new conservatism rejected stodgy traditional conservatism in favor of a frontier-accented doctrine of individualism, self-reliance, economic liberty, social mobility, and entrepreneurship. Goldwater would go down to crushing defeat in 1964, but his new conservatism would reshape the Republican Party and emerge triumphant with the 1980 election of Ronald Reagan.

Often misunderstood has been the latent conflict implicit in the coexistence of Goldwater-style radical individualism and conventional Republican localism, especially in the realm of education. On one hand, the Goldwaterite commitment to opportunity and individual responsibility resonated with suburban and Southern voters concerned with the welfare state. ${ }^{6}$ However, voters also believed in the implicit promise that the playing field ought to be levelthat everyone deserved to have a chance to succeed. ${ }^{7}$ Without a visible commitment to increasing opportunities for the disadvantaged, Goldwaterism risked appearing merely an excuse for injustice. However, visible efforts to combat social and economic inequality would imply a commitment to federal activity at odds with the Republican heritage of decentralization, small government, minimal redistribution, and the centrality of the family. Henceforth, Republicans would struggle to plausibly promote equal opportunity while seeking to minimize redistribution and maximize local control. 
Unlike the Republicans, Democratic leaders were comfortable with active federal involvement in education. After defeating Goldwater in 1964, Lyndon Johnson continued to push an expansive social agenda, including the 1965 ESEA, the first comprehensive package of federal aid to education. An aggressive federal educational role fit neatly with the New Deal paradigm of an activist government, public investment, and social insurance. The Democratic stance on education also appealed to the urban, Black, labor, and intellectual components of the party's New Deal coalition. Support for national control and desegregation caused consternation, however, among Southern Democrats. In part due to educational tensions, the ties binding Southern Democrats to the New Deal coalition began to unravel.

George Wallace, governor of Alabama and ardent segregationist, seized on discontent among Southern Democrats in his 1968 third-party presidential campaign. Running as a critic of federal activism on a variety of fronts (most visibly desegregation), Wallace won 46 electoral votes and $14 \%$ of the popular vote (10 million votes). In 1968, a majority (54\%) of Americans thought that the Johnson administration was pushing integration too fast, and an equal number favored cutting government spending on domestic programs. ${ }^{8}$ Republican candidate Richard Nixon, tapping into voter concerns about civil unrest, law and order, and the Vietnam War, would narrowly defeat Lyndon Johnson's vice president Hubert Humphrey to win the general election. Because Nixon did not mount an aggressive critique of Johnson's activism, he had little difficulty in straddling the divisions that had arisen among the conflicting wings of the Republican Party.

During the next 4 years, the federal courts required a number of northern cities to engage in extensive busing programs designed to overcome public school segregation. Reviled by working-class and ethnic White voters, busing helped to undermine support for activist government and threw Democrats on the defensive. Nixon's massive 1972 presidential election victory demonstrated that Republicans could capitalize on this discontent. By focusing on the more ambitious and race-conscious elements of Johnson's Great Society and the cultural radicalism that characterized the student left, the Republicans depicted a Democratic Party that had abandoned mainstream America. The 1972 Democratic nominee, George McGovern, a diffident South Dakotan, was effectively tagged the candidate of "amnesty, acid, and abortion."

The challenge for the Democratic leadership would be maintaining the party's commitment to the disadvantaged while countering the notion that support for civil rights and redistribution made them the party of the handout. The problem receded in the 1976 election, when former Georgia governor 
Jimmy Carter eked out a victory on the basis of his moderate positions and popular revulsion with the Watergate scandal.

In the 1976 election, for the first time, both the National Education Association (NEA) and the American Federation of Teachers (AFT) endorsed a presidential candidate, throwing their support behind Carter. This alliance would lend the Democrats useful political muscle and would give the Democrats enhanced education credibility but would simultaneously bind the Democratic stance on education to the preferences of the nation's public school teachers. In winning the support of the NEA and AFT, Carter committed himself to establishing a cabinet-level Department of Education. The department was created in 1979 , and by 1980 , it administered approximately 500 federal education programs.

During the Nixon years, Republicans began to dream of winning over enough disaffected Democrats to construct a new national majority. Republican opposition to busing and support for local schooling had a powerful appeal for working-class, White urban and suburban Democrats. These efforts, along with growing Republican strength in the South, would mark the end of the New Deal coalition.

In the late 1970s, the nascent campaign of Reagan promoted a number of proposals with particular appeal for the nation's 50 million Catholics, a historically Democratic group that had grown disenchanted with the party's cultural liberalism. In particular, Reagan voiced his opposition to abortion, argued for permitting prayer in school, and called for school vouchers that would permit public funds to support parochial school tuition. ${ }^{9}$

The 1965-to-1980 period produced three key changes. First, the Republicans learned that they could effectively attack traditional liberal largesse. Second, the Democratic Party's national majority unraveled as racial and cultural tensions weakened support among Southerners, working-class Whites, Catholics, and suburban voters. Third, the Democrats established themselves as the party of education, largely by embracing the nation's public school teachers and by advocating steady increases in federal education spending. Meanwhile, the Republican stance on education became characterized by opposition to federal spending and criticism of many public school practices.

\section{THE TRIUMPH OF AN OPPORTUNITY-BASED CONSERVATISM: 1980-1992}

In 1980, Carter was challenged by Goldwater heir Reagan. Reagan attacked Carter for being weak on the Soviets abroad and for supporting an intrusive and stifling welfare state at home. He argued that Democrats had abandoned equality of opportunity in favor of equality of results and that this 
shift was to blame for the nation's stagnant economy and general malaise. Reagan's message resonated with voters seeking to find a scapegoat for the environment of high unemployment, high inflation, and low growth, and his call for slashing taxes and government spending won wide support. ${ }^{10}$ As part of this general attack on government, the 1980 Republican platform called for "deregulation by the federal government of public education and . . the elimination of the federal Department of Education"; the platform fretted that "parents are losing control of their children's schooling" and that Democratic education policy had produced "huge new bureaucracies to misspend our taxes" (Historic Documents of 1980, 1981, pp. 583-584).

Reagan offered a domestic policy agenda that satisfied his Goldwaterite allies, the traditional conservatives, and the disaffected Democrats by promising to roll back the federal government and still provide opportunity to the disadvantaged. Reagan proposed to accomplish this through his "new federalism" initiative. He managed to call for less government while appearing sensitive to the need for a level playing field by arguing that the federal government obstructed social and economic progress and that the states were better equipped to safeguard opportunity for all. For instance, Reagan was able to call for abolishing the new Department of Education without being seen as anti-education. Although generally supportive of the department, voters supported Reagan's proposal to transfer federal education programs to the local level by a $62 \%$ to $21 \%$ margin. ${ }^{11}$ Overall, Reagan operated at a disadvantage on education, with Democrats enjoying a 9-point advantage over Republicans on the issue in 1979 (see Table 3), but the point was of little significance given the strength of Reagan's broader appeal.

In 1981, Reagan reformed many of the provisions of ESEA when he won passage of the Education Consolidation and Improvement Act. The changes reduced federal funding for education by almost $20 \%$ and increased the flexibility of states in the use of federal education funds. The reduction in federal funding and control, however, would be used by Democrats to question the depth of the Republican commitment to equal opportunity. Also in 1981, Reagan named a high-profile commission to produce a report on the state of American education. The commission's widely publicized report, A Nation at Risk (National Commission on Excellence in Education, 1983), painted a dire portrait of American schooling and argued that the nation's failure to keep pace with the educational system of Japan-whose economy had become the envy of the world-had put its future at risk.

The Reagan administration's opposition to activist social policy meant that the reforms prompted by the report emerged at the state level. Foreshadowing changes to come, many of the leaders of these reform efforts were moderate Southern Democratic governors such as Charles Robb of Virginia, 
Table 3

Public Attitudes Toward the Ability of the Major Parties to Address Education, 1979-2000

\begin{tabular}{lccl}
\hline Year & Democrats $(\%)$ & Republicans $(\%)$ & Advantage \\
\hline 1979 & 25 & 16 & Democrats +9 \\
1984 & 37 & 19 & Democrats +18 \\
1988 & 55 & 22 & Democrats +33 \\
1992 & 42 & 17 & Democrats +25 \\
1996 & 59 & 30 & Democrats +29 \\
2000 & 44 & 41 & Democrats +3 \\
\hline
\end{tabular}

Source. Assorted polls from the Roper Center for Public Opinion Research at the University of Connecticut (n.d.).

Note. Question wording varied slightly from year to year. In 1979, the wording was as follows: "I'm going to read you the list of problems and issues facing the country, and as I read each one, I would like you to tell me whether you think the Republican or the Democratic party would do the better job of handling that particular problem or issue . . . ensuring the quality of education." In 1984, the wording was as follows: "Here are some goals for the nation that many people believe will be important in the 1984 election. As I read each one, please tell me whether you feel the Republican party or the Democratic party would do a better job in handling that issue or don't you think there's any real difference between them? Providing quality education." In 1988, the wording was as follows: "Regardless of how you are likely to vote, do you think the Republican party or the Democratic party will do a better job of improving education in America?" In 1992, the wording was as follows: "Let me read you a list of some specific issues. When it comes to dealing with education which party do you think would do a better job - the Democratic party, the Republican party, neither, or are both about the same?" In 1996, the wording was as follows: "Do you think the Republican party or the Democratic party would do a better job of dealing with each of the following issues and problems . . . education?" In 2000, the wording was as follows: "I am going to ask you something different. I am going to read a list of issues and I want you to tell me whether, overall, you think the Democrats or the Republicans would do a better job with this issue.... Education. Do you think the Democrats of Republicans would do a better job with that? Would that be much better of somewhat better?"

Bill Clinton of Arkansas, and Bob Graham of Florida. In some ways, the surge of state activity bolstered Reagan's argument that the states were the appropriate forum for tackling education reform. In fact, even after the issuance of A Nation at Risk (National Commission on Excellence in Education, 1983), the 1984 Republican platform would assert, "From 1965-1980 the U.S. indulged in a disastrous experiment with centralized direction of our schools" (Historic Documents of 1984, 1985, p. 690). By 1984, the tumult generated by A Nation at Risk would cause the public, for the first time, to rank education in the top tier of its concerns (see Table 1).

During the 1984 campaign, President Reagan attacked his Democratic opponent Walter Mondale — formerly vice president under Carter-as another apologist for welfarism. Against a backdrop of surging economic growth, increasing public satisfaction at home, confidence in American foreign policy abroad, and affection for Reagan himself, Mondale's efforts to defend federal programs and attack Reagan as callous fared poorly. ${ }^{12}$ Amidst concerns 
over economic conditions and the cold war, Democratic attacks on Republican fairness gained little traction, and Reagan crushed Mondale in a 49-state landslide.

In 1985, after Reagan's second victory, Southern governors and other moderates who felt threatened by the liberalism of the national party formed the centrist Democratic Leadership Council (DLC). Offering a vision of limited government, public investment, and fiscal prudence, the DLC leadershipincluding such rising figures as Arkansas governor Clinton and Tennessee senator Al Gore-sought to refashion the New Deal-era Democratic commitment to redistribution. Focused on finding a new way to balance responsibility and opportunity, the "new Democrats" found education and welfare reform to be areas of pressing interest.

In 1988, Reagan's vice president, George H. W. Bush, was challenged by Michael Dukakis, the three-term governor of Massachusetts and a conventional good-government liberal. However, given the public's satisfaction with 8 years of Republican rule and the continuing skepticism with increased federal activity, Dukakis sought to campaign on "competence" rather than "ideology." This marked the first time a Democratic presidential nominee had explicitly sought to distance himself from the party's activist legacy. The Bush campaign, however, successfully depicted Dukakis as another tax-and-spend liberal in the mold of McGovern, Carter, and Mondale, in the process turning a substantial early Dukakis lead into an 8-point Bush victory.

A Nation at Risk had put education on the national agenda. In 1988, education again ranked among the public's top concerns (see Table 1). In particular, there was ongoing public agreement that education standards ought to be raised. For instance, a 1987 Gallup poll found that $84 \%$ of Americans thought that the federal government should require state and local educational authorities to meet minimum national standards. ${ }^{13}$ Both wings of the Republican Party, however, were opposed to such a federal intrusion into the prerogatives of local government. Republican opposition to standards and to Democratic calls for more federal educational spending left the Republicans in a very vulnerable position. In fact, in 1988, by a massive $55 \%$ to $22 \%$ margin, the public thought that Democrats would do a better job of improving education than Republicans (see Table 3). Seeking to address this weakness, Bush campaigned in 1988 by declaring his intention to govern a "kinder, gentler nation" and to be "the education president." The 1988 Republican platform took a slightly softer tone than the 1984 platform, acknowledging the case for a limited federal role in education but declaring "parents have the primary right and responsibility for education" (Historic Documents of 1988, 1989, p. 723). 
One significant development in the campaign was the shifting Republican approach to school choice. Reagan's choice rhetoric had focused on appealing to disaffected Catholics, but in 1988 Republicans began a tentative effort to use school choice as a way to neutralize the party's weakness on education and the fairness issue. In particular, the Republican platform voiced its support for federal school vouchers as a way to "empower [low-income families] to choose quality ... schooling" (Historic Documents of 1988, 1989, p. 723). School choice held a natural attraction for the Republicans by promising a way to address educational concerns without expanding the federal government's role.

Republican efforts to effectively wield school choice, both during the Bush administration and throughout the 1990s, would be hobbled by the party's inability to convince voters of its commitment to serving the disadvantaged. In particular, Republicans tried to portray school choice as a civil rights issue-focusing on the ability of school vouchers and charter schools to help African American and urban youths trapped in inferior schools. They sought to use growing national support for school choice-especially among African Americans and urban residents-to dispel the perception that the Republican Party was unconcerned with the plight of the disadvantaged. However, for a variety of reasons, including the frosty reception of the established civil rights leadership, continued minority skepticism of the modern Republican Party, and the effectiveness of Democratic efforts to paint ReaganGoldwater Republicanism as callous, the Republicans were unable to use this appeal to broaden their support among either minorities or swing voters. In general, public affection for the public schools, concern about the inequities inherent in market-based arrangements, and suspicion about Republican motives rendered the choice-based approach to school improvement politically ineffective.

Unable to make headway on school choice and reluctant to mount a potentially damaging fight but recognizing the salience of education and the need to do something, the Bush administration opted for a largely rhetorical push that featured a historic gathering of the nation's governors in 1989. From that meeting emerged six education goals that would form the crux of the symbolically potent America 2000 reform plan that Bush would offer with much fanfare. Although Bush did not call for any substantive increase in federal involvement in education, his efforts marked a significant break with Republican tradition and were attacked by congressional Republicans for threatening to nationalize education.

During the 1980s, presidential elections turned on foreign policy and Republican critiques of Great Society-style social welfare policies. By forcing Democratic nominees to defend an increasingly costly and unpopular 
Table 4

Public Attitudes Toward the Major Party Candidates on Education, 1984-2000

\begin{tabular}{llll}
\hline Year & Democrat $(\%)$ & Republican $(\%)$ & Advantage \\
\hline 1984 & 42 (Mondale) & 39 (Reagan) & Democrat +3 \\
1988 & 51 (Dukakis) & 34 (Bush) & Democrat +17 \\
1992 & 47 (Clinton) & 24 (Bush) & Democrat +23 \\
1996 & 64 (Clinton) & 31 (Dole) & Democrat +33 \\
2000 & 44 (Gore) & 42 (Bush) & Democrat +2 \\
\hline
\end{tabular}

Source. Assorted polls from Roper Center for Public Opinion Research at the University of Connecticut (n.d.).

Note. Question wording varied slightly but respondents were asked a variation of "Which candidate do you think would do a better job on education?" In 1992, Perot was listed as a third choice for respondents, thus lowering the totals for each of the major two party candidates.

federal welfare state, neither Reagan nor Bush had to offer much more than a general rejection of Great Society-style liberalism. However, as Bush's 1988 pledge to be the education president hinted, growing public attention to education and emerging concern with the Republican commitment to equal opportunity would eventually force the Republicans to develop a more substantive response.

\section{THE NEW DEMOCRATS STRIKE BACK: 1992-2000}

The end of the cold war changed the dynamic of presidential elections-in particular, it elevated the profile of domestic policy. In 1992, the Democrats would capitalize in dramatic fashion. Amidst the string of defeats in the 1980s, moderate Democrats had argued that the party needed to win back swing voters by shedding the party's tax-and-spend reputation. At the same time, the party could not afford to alienate its core urban and minority supporters. Seeking to negotiate this tension, the new Democrats pioneered a rhetoric that emphasized expanding opportunity and shared responsibility, arguing that a skill- and knowledge-based economy required the workers' party to shift from a redistributive model toward one that fostered societal investment in workers. ${ }^{14}$

The 1964 revolution had left Republicans vulnerable on the issues of fairness and opportunity, should the Democrats ever escape the "big government" label. In 1992, the Democrats slipped that noose, as nominee Clinton jettisoned the rhetoric of redistribution and offered instead a call for investment and equal opportunity. Rather than defending the welfare state against charges of indulgence or irresponsibility, he charged that the Republicans had not kept their promise to give all Americans the chance to succeed. ${ }^{15}$ Polls showed that voters thought Clinton better able than Bush to improve 
public education—by a staggering $47 \%$ to $24 \%$ margin (see Table 4 )—and that education had climbed to the point where voters consistently listed it as one of their top five priorities (see Table 1). In the fall of 1992, Clinton unseated President Bush on the strength of the new Democratic appeal.

The Democrats' effort to reposition themselves was evident in the party's 1992 platform, which proclaimed, "Rather than throwing money at obsolete programs, we will eliminate unnecessary layers of management, [and] cut administrative costs" (Historic Documents of 1992, 1993, pp. 697-698). On education, the platform argued, "Governments must end the inequalities that create educational ghettos among school districts and provide equal educational opportunity for all" but also acknowledged that schools must be held accountable to "high standards of educational achievement" (pp. 697-698).

This rhetoric put the Republicans on the defensive, exposing the tension between the party's commitment to individual opportunity and its rejection of activist social policy. Seeking to honor both imperatives, Bush was forced to either deny the existence of social and economic inequities or to deny that there was anything government could or should do to help. In the face of public discontent stirred by a recession, this awkward stance left Bush seeming ineffectual and out of touch. The Democrats had finally found a way to exploit the latent conflict between the Republican promise of an opportunity society and the party's rejection of government activism as a means to that end.

During and after the 1992 election, the Republicans struggled to answer the challenge posed by the new Democrats without abandoning the party's historic principles. Two main means of response were available; both were by now familiar. One called for Republicans to more aggressively advocate choice-based reforms, such as public school choice, charter schooling, and school vouchers. In 1990 and 1991, charter schooling and school vouchers had enjoyed their first state-level legislative successes. A second school of thought endorsed national standards and increased accountability that Bush had first proposed in 1989. In the words of the 1992 platform, "The critical public mission in education is to set tough, clear standards of achievement and ensure that those who educate our children are accountable for meeting them" (Historic Documents of 1992, 1993, p. 809). This approach had the advantage of demonstrating a clear commitment to ensuring that all students were educated effectively, of holding the public education establishment's feet to the fire, and of offering a basis for increasing the academic rigor of $\mathrm{K}-12$ curricula.

The problem with the standards-based approach for Republicans was that it represented the first step on a slippery slope toward nationalizing curricula and schooling. This was the concern that had sunk Bush's America 2000 plan, and it would cause the Republicans, in the end, to choose to shy away 
from any national system of accountability during most of the 1990s. In fact, congressional Republicans would attack Clinton's Goals 2000 plan for its proposal that the federal government encourage the development of national standards and play an active role in coordinating and supporting state testing.

Republicans made historic gains in the 1994 midterm elections. Riding backlash against Clinton's ambitious health care proposal—which brought back memories of Democratic big government - the Republican leadership launched an ambitious effort to roll back the federal government and abolish several cabinet agencies. Republicans handed Clinton a significant political opportunity when they called for the abolition of the Department of Education. Voters rejected Republican proposals to cut spending for the Department of Education, by $79 \%$ to $15 \%$, and to eliminate the Department altogether, by $80 \%$ to $15 \% .{ }^{16}$ The Republican proposals permitted Democrats to depict the Republicans as hostile to education.

In 1996, U.S. Senate Majority Leader Robert Dole, a bastion of the party's traditional wing, was the Republican presidential nominee. Dole fared no better than Bush had at countering the new Democrat credo, and Clinton beat him by a comfortable margin. Dole's proposed $15 \%$ tax cut and his attacks on the Clinton administration withered under Democratic claims that the Republicans were the party of the rich. Like Bush, Dole sought to counter Democratic appeals on education by arguing that federal involvement was counterproductive. Dole attacked the teachers unions as emblems of the Democratic attachment to big government and bureaucracy, again arguing that school vouchers could provide a coherent response to concerns about educational quality. However, even though choice-based reforms enjoyed significant support among minority and urban voters, Dole's efforts fell flat and continued to leave the Republicans vulnerable to charges of being anti-education. In the end, Clinton again massively outpaced his Republican opponent on the education question, leading Dole $64 \%$ to $31 \%$ when the public was asked who was better equipped to promote educational quality (see Table 4). Reflecting the heightened profile of education, $86 \%$ of Americans indicated in 1996 that the candidates' education policies were extremely important or very important in determining their presidential vote. ${ }^{17}$

More significant than the particulars of the educational debate in 1996 was the fact that Clinton, after the 1994 health care debacle, reestablished the party's new Democrat credentials. Attacks on the Democrats as permissive and indulgent no longer possessed the razor teeth they once had. Both parties now offered visions of an America characterized by opportunity and selfreliance. Particularly useful for the Democrats was that the terms of the debate now enabled them to again champion federal activism, so long as they used a rhetoric of equal opportunity rather than of redistribution. This 
allowed centrists to cater to the party's base while crafting an appeal more amenable to suburbanites and Southerners.

\section{CONVERGENCE-OPPORTUNITY THROUGH ACCOUNTABILITY: THE 2000 ELECTION}

Education allowed the new Democrats to repackage government activism as an effort to ensure that all Americans have the opportunity to succeed. To answer this challenge, the Republicans would need to find a way to repackage the party's opposition to expansive federal activity. Republican policy makers had long hoped that the party's support for choice-based reforms would solve this problem, but after nearly a decade, the party's efforts on that front continued to yield almost no electoral gains. In fact, critics such as the NEA and the National Association for the Advancement of Colored People enjoyed substantial success in depicting school choice as segregationist and wielding it against the Republicans.

In 2000, the Republicans nominated Texas governor George W. Bush, son of the former president. Bush trumpeted a "compassionate conservatism" that argued that government could play a constructive role but that individuals and communities ultimately had to be responsible for themselves. Pivotal to Bush's vision was his emphasis on education and the promise that "no child would be left behind." Bush's views were spelled out most clearly in his widely discussed "duty of hope" speech, delivered in Indianapolis on July 22, 1999, which offered a proactive Republican program for democratizing opportunity while rejecting Great Society-style liberalism. Bush proclaimed that his would "not be the failed compassion of towering, distant bureaucracies" ("In Their Own Words," 1999, p. A16). Bush also, however, pointedly criticized conservatives who denied that the federal government could play a constructive role in addressing social problems. He dismissed those with "a destructive mindset: the idea that if government would only get out of the way, all our problems would be solved" ("In Their Own Words," 1999, p. A16). The Bush rhetoric implied that a conservative government had a role to play in ensuring that all citizens enjoyed an opportunity to succeed and that education would be central to that vision.

As governor of Texas, Bush had championed the state's stringent accountability plan as a means to ensure that all children-especially Hispanic and Black children and those in urban areas-were receiving an adequate education. As governor, the credibility he had earned with his staunch support of accountability and his successful effort to reach out to minority communities had permitted Bush to advocate school choice, oppose significant increases in educational expenditures, and criticize the public school establishment. 
Where previous Republicans had appeared anti-education when they took similar stands, Bush's credible commitment to educating all students had permitted him to argue that he was proeducation even when he opposed funding measures or criticized the existing public school system.

During the 2000 campaign, Bush would promote his attention to education as evidence of his compassion and would use it to blunt arguments that Republican opposition to federal spending showed disregard for the poor. Bush would effectively resurrect the Reagan argument that the Republicans wanted to help the disadvantaged and that the best way to do so was to provide opportunities. However, where Reagan had promised that expanding opportunity required getting liberal government out of the way, Bush argued that it required government to ensure that the liberal education and social welfare establishment was being held accountable for serving disadvantaged children and citizens in need. The Bush appeal served to implicitly put the onus for social problems on ineffective public agencies and employees-in the case of schooling, on school districts and teachers-and enabled him to end the longstanding Republican deficit on education by achieving near parity with his Democratic opponent on the question of educational leadership (see Table 4). ${ }^{18}$

Vice President Al Gore, the Democratic nominee, responded to Bush's efforts by proposing significantly more spending than Bush, supporting public school choice, and calling for the federal government to provide special assistance to improve low-performing schools. As had Clinton in 1992 and 1996, Gore tried to use his support for educational spending to attack Bush's commitment to schooling. However, Bush's strong stance on accountability and experience in Texas, coupled with a small number of targeted spending proposals, permitted him to parry Gore's attacks by painting Gore as a captive of the public school establishment. This response helped Bush to tap into quiescent concerns that Democrats were using investment and opportunity as excuses to tax and spend. For the first time in more than two decades, the Republicans were able to battle the Democrats to a near standstill on the education question (see Table 3 ). This proved crucial, as voters ranked education the nation's most important issue in an election where Bush eked out an electoral college victory (see Table 1).

The problem for Republicans was that the triumph of compassionate conservatism came at a cost. In countering the Democratic accusations of callousness, it implied a commitment to an expanded federal role in education. Meaningful national accountability required that Washington become proactive in the selection and implementation of accountability systems. Moreover, having positioned himself as a champion of education, Bush 
would find it awkward to oppose Democratic efforts to increase federal education spending. Bush's stance strengthened the Republican hand on education and a broad array of policy debates, but it proved to be an unhappy bargain for traditional Republicans and for the radical critics of federal interventionism. The expanded federal role marked a historic departure from Republican doctrine and created the likelihood of future conflicts between the proponents of the opportunity society and the traditional defenders of state and local prerogatives.

\section{CONCLUSION}

To a much greater extent than is recognized, education has helped to shape the themes of presidential and national party politics in recent decades. Education's potent marriage of opportunity and equality and its implicit emphasis on self-reliance made it a defining metaphor as the parties wrestled with post-Great Society politics. Moreover, a changing economy, the universalization of education, and the receding profile of foreign policy helped make education an issue of increasing importance.

From 1932 to 1964, Democrats had enjoyed wide support for federal programs designed to expand opportunity and to construct a safety net to protect the unfortunate. So long as the unfortunate appeared to be suffering unjustly, this program could plausibly advance opportunity without undermining responsibility. However, by the 1970s and 1980s, images of food stamp cheats and welfare queens fostered the impression that Great Society-style liberalism was inimical to personal responsibility. The rise of the new conservatism that first emerged in 1964 provided Republicans with an opportunity-oriented alternative to the Great Society-style liberalism that they charged with undermining the nation's sense of responsibility, unraveling its cultural fabric, and threatening its economic well-being.

The Republican vision of an opportunity society built on individual responsibility proved effective so long as Democrats were unable to plausibly challenge Republican commitment to expanding opportunity. By the beginning of the 1990s, however, the new Democrats were able to effectively attack the Republicans for appearing unconcerned with providing opportunity for the needy and the disadvantaged. Much as the Democratic presidential defeats in the 1980s allowed the new Democrats to emerge, so the Republican defeats in 1992 and 1996 left the party establishment willing to consider new approaches to domestic policy, such as compassionate conservatism. It was no coincidence that both the new Democrats and the compassionate conservatives emphasized education, because it permitted the parties to address deep-seated national attachments to both opportunity and responsibility. 
Finding a way to simultaneously accommodate both imperatives had proved to be the central challenge to domestic policy since the mid-1960s.

In each case, it was not until the costs of the status quo became apparent to party leaders that entrepreneurs were able to alter party positions over the protestation of entrenched constituencies. Both the new Democrats and the compassionate conservatives moderated existing party stances as they sought to broaden the base of party support. In doing so, they angered established interests, retraced the fault lines in debates over public policy, and changed the way the public thinks about education and its relationship to partisan politics. Why entrepreneurs are sometimes able to recast party positions and how those efforts affect an issue's salience are important questions deserving of a systematic treatment. Unfortunately, these questions are beyond the scope of this article.

Typically, it is difficult for party leaders to overcome the commitments and constituencies that resist changes to established policy positions, although it becomes much easier for entrepreneurs to sell politically useful changes once the costs of the status quo become clear. Reformers have an easier time making such changes when they are aligning policy positions with party ideology, as was the case with Republicans and school choice. However, the need to broaden public support dictates a need to court the median voter, which often creates conflict with party ideology — as in the case of George W. Bush and accountability. The resulting tensions, when issues are sufficiently salient, may alter coalitions, create new political dynamics, and foster broader changes in the party system. Entrepreneurs will tend to favor issues of intense public concern. However, the ongoing search for new targets of opportunity and the corresponding responses can attract attention to issue areas that previously attracted little notice (Baumgartner \& Jones, 1993). Once this process brings an issue to national attention, candidates are obliged to address it. Thus is launched a self-reinforcing cycle that may last until the parties settle into a new equilibrium or until an external shock changes the terms or focus of political debate.

In a contemporary polity marked by a historic degree of party parity and in which education enjoys unprecedented visibility, both parties struggle to attract moderate voters without alienating established constituencies. The Democrats wish to expand federal support for education without appearing to simply use the rhetoric of opportunity to mask a broadly unpopular agenda of redistribution. Their alliance with the teachers' unions makes it necessary to emphasize educational spending and nonpunitive measures while seeking to avoid appearing a captive of the public school establishment. These pressures lead Democrats to endorse increased federal spending, plausible-but ultimately limited - accountability measures, and public school choice. They may 
also lead centrist Democrats to rebel against the constraints imposed by the party's alliance with the teachers' unions and public school establishment.

Meanwhile, Republicans seek to sustain support for accountability, which is an approach that can serve as a significant and visible commitment to democratizing educational quality but which risks alienating localist and antigovernment Republicans. Republicans also continue to hope that choice-based reform will permit them to address educational opportunity with a program that does not subject the party to such intense internal stress, but they are cautious about the possible political perils. Finally, the Republicans feel compelled to accept some increases in federal education spending, if only to protect their hard-won credibility on the issue.

The convergence of the parties on education was evident in the remarkable degree of bipartisan agreement and broad moderate leadership that characterized the 2001 ESEA reauthorization, when the parties readily agreed on substantially increased federal spending, modestly enhanced public choice, and the framework of a national accountability system that would have been unthinkable just a few years before. Although the shape of this compromise was anything but accidental, it would be a mistake to see this long story as one of a steady march toward an inevitable equilibrium. Rather, the convergence of 2000 is likely to prove no more permanent than the preceding periods of one-party dominance, and it is likely to be felled by internal Republican tensions over accountability or internal Democratic tensions over the role of the teachers unions. How these tensions play out will influence the context of presidential elections for years to come. It will also have telling effects on the future of educational policy regarding spending, standards, and school choice.

\section{NOTES}

1. It should be noted that some observers, such as Kanstoroom and Finn (1999), argue that the actual federal impact on schooling far exceeds its limited share of total expenditures.

2. Morone (1998), for example, has argued that a powerful democratic wish, imbued with notions of equality and a shared obligation to democratize opportunity, resonates in American political culture.

3. However, the exceptionally committed might resort to a third-party bid if they come to believe it is the only way to remain true to their views or to force their party back to its roots (Downs, 1957, pp. 131-132).

4. The one exception may have occurred during the 1876 election cycle, when House Speaker James G. Blaine pushed for adoption of the anti-Catholic "Blaine Amendment" (a proposed constitutional amendment stating that public money could not fund sectarian schools) in the hopes that it would help him claim the Republican presidential nomination. However, the amendment failed in the U.S. Senate, and there is little evidence that it did much to help Blaine in his failed quest for the nomination. 
5. See, for instance, Peterson (1985, pp. 5-22), Katz (1987, pp. 16-20), or Ravitch (2000, pp. 241-247).

6. In 1964, for example, $79 \%$ of respondents to one poll agreed that "we should rely more on individual initiative and ability and not so much on governmental welfare programs" (Roper Center for Public Opinion Research at the University of Connecticut, September 1964, Accession Number 0038345, Question Number 52). Obviously, any effort to use historical polling data runs into questions about which polls ought to be used. The authors have sought to only use reputable polls that generated results consistent with other contemporaneous surveys. Nonetheless, we urge readers to view the numbers as illustrative and not to overemphasize any single poll result. In constructing the accompanying tables, the authors sought to maximize comparability over time by using polls conducted at similar times in the election cycle, by the same survey firm, and with similar question wording.

7. For instance, when the same 1964 poll asked respondents to identify what was responsible for holding unsuccessful people back in life, the most common response was "lack of education and training" (Roper Center for Public Opinion Research at the University of Connecticut, September 1964, Accession Number 0038345, Question Number 61).

8. Roper Center for Public Opinion Research at the University of Connecticut, February 1968 (Accession Number 0101680, Question Number 15) and September 1968 (Accession Number 0041300, Question Number 24).

9. In the 1980 election, Reagan would go on to win 55\% of Catholic independents and $28 \%$ of Catholic Democrats (Sundquist, 1983, p. 582).

10. For instance, a 1980 poll showed that $71 \%$ of respondents wanted the government to cut spending, and just 19\% opposed such cuts (Roper Center for Public Opinion Research at the University of Connecticut, August 1980, Accession Number 0029241, Question Number 45).

11. Roper Center for Public Opinion Research at the University of Connecticut, November 1980, Accession Number 0078877, Question Number 20.

12. However, even at the height of Reagan's popularity, he could not alleviate the public perception that Democrats were more concerned with ensuring opportunity for all than were Republicans. For instance, when a 1984 poll asked voters, "Which [candidate] would do a better job of insuring that government programs and policies are fair to all people?" respondents preferred Mondale over Reagan by a 53\% to $40 \%$ margin (Roper Center for Public Opinion, September 1984, Accession Number 0005299, Question Number 51).

13. Roper Center for Public Opinion Research at the University of Connecticut, April 1987, Accession Number 0044505, Question Number 25.

14. In 1990, the Democratic Leadership Council issued the "New Orleans Declaration: A Democratic Agenda for the 1990s," which specifically called for replacing the "politics of entitlement with a new politics of reciprocal responsibility."

15. For a more extended discussion, see Baer (2000, pp. 159-192).

16. Roper Center for Public Opinion Research at the University of Connecticut, March 1995 (Accession Number 0232151, Question Number 16) and June 1995 (Accession Number 0237493, Question Number 24).

17. Roper Center for Public Opinion Research at the University of Connecticut, October 1996, Accession Number 0332381, Question Number 28.

18. Commentators noted that, "Bush has made dramatic strides in neutralizing what has traditionally been one of the Democrats' strongest issues. Voters rated Bush and Gore roughly equal on their abilities to deal with education, a historic shift in attitudes over past campaigns when the Republican candidate often trailed the Democrat by a wide margin on the issue" (Balz \& Morin, 2000). 


\section{REFERENCES}

Baer, K. (2000). Reinventing Democrats: The politics of liberalism from Reagan to Clinton. Lawrence: University of Kansas.

Balz, D., \& Morin, R. (2000, June 30). Education voters pose a tough test. The Washington Post, p. A1.

Baumgartner, F., \& Jones, B. (1993). Agendas and instability in American politics. Chicago: University of Chicago.

Burnham, W. (1970). Critical elections and the mainsprings of American politics. New York: Norton.

Carmines, E., \& Stimson, J. (1989). Issue evolution: Race and the transformation of American politics. Princeton, NJ: Princeton University.

Downs, A. (1957). An economic theory of democracy. New York: HarperCollins.

Feldman, S. (1988). Structure and consistency in public opinion: The role of core beliefs and values. American Journal of Political Science, 32, 416-440.

Hirschman, A. (1970). Exit, voice, and loyalty. Cambridge, MA: Harvard University.

Historic documents of 1980. (1981). Washington, DC: Congressional Quarterly.

Historic documents of 1984. (1985). Washington, DC: Congressional Quarterly.

Historic documents of 1988. (1989). Washington, DC: Congressional Quarterly.

Historic documents of 1992. (1993). Washington, DC: Congressional Quarterly.

In their own words: Excerpts from a July 22 speech by Texas Gov. George W. Bush on faith-based organizations, delivered in Indianapolis, Ind. (1999, July 29). Star Tribune, p. A16.

Katz, M. (1987). Reconstructing American education. Boston: Harvard University.

Kanstoroom, M., \& Finn, C. (Eds.). (1999). New directions: Federal education policy in the twenty-first century. Washington DC: Thomas B. Fordham Foundation.

Kingdon, J. (1995). Agendas, alternatives, and public policies. New York: HarperCollins.

Kursh, H. (1965). The United States Office of Education: A century of service. New York: Chilton Books.

Markus, G. (1988). The impact of personal and national economic conditions on the presidential vote. American Journal of Political Science, 32, 137-154.

Milkis, S. (1995). The presidency and the political parties. In M. Nelson (Ed.), The presidency and the political system. Washington, DC: Congressional Quarterly.

Mintrom, M. (2000). Policy entrepreneurs and school choice. Washington DC: Georgetown University.

Morone, J. (1998). The democratic wish. New Haven, CT: Yale University.

National Center for Education Statistics. (2000). Digest of education statistics 1999. Washington, DC: Department of Education.

National Commission on Excellence in Education. (1983). A nation at risk: The imperative for educational reform. Washington, DC: U.S. Department of Education.

Peterson, P. (1985). The politics of school reform: 1870-1940. Chicago: University of Chicago.

Ravitch, D. (1983). The troubled crusade: American education 1945-1980. New York: Basic Books.

Ravitch, D. (2000). The great school wars: A history of the New York City public schools. Baltimore: Johns Hopkins University.

Roper Center for Public Opinion Research at the University of Connecticut. (n.d.). Public opinion online. Retrieved from www.lexis-nexis.com/universe/form/academics/s_roper.html?

Sundquist, J. (1983). Whither the American party system? Revisited. Political Science Quarterly, 98, 573-593. 
Thompson, K. (Ed.). (1990). The presidency and education. Lanham, MD: University Press of America.

Tyack, D. (1974). The one best system: A history of American urban education. Cambridge, MA: Harvard University.

U.S. Department of Commerce. (1999). Education of the American population. Washington, DC: U.S. Census of Population.

Wirt, F., \& Kirst, M. (2001). The political dynamics of American education. Berkeley, CA: McCutchan. 